\title{
Maxillary brown tumor associated with chronic kidney failure: a case report
}

\section{Tumor marrom na maxila associado à insuficiência renal crônica: relato de caso}

Stênio Medeiros Queiroz'; Rodrigo Gadelha Vasconcelos²; Ana Luiza Dias Leite de Andrade;

Adriana Gomes Amorim; Manuel Antonio Gordón-Nuñes; Roseana de Almeida Freitas'; Hébel Cavalcanti Galvão ${ }^{6}$

\begin{abstract}
The brown tumor is a bone lesion that may affect the entire skeleton, including the maxillary bones. These tumors are characterized as focal giant cell lesions that may be associated with primary or secondary hyperparathyroidism (HPT). Brown tumors are invasive in some cases and an association with chronic renal failure (CRF) has been reported. With the aim to facilitate the differential diagnosis of bone lesions that may affect dialysis patients, this paper describes a case of brown tumor in a 36- year old patient with CRF, secondary HPT carrier, who had a lesion on the right maxilla for approximately five months.
\end{abstract}

Key words: secondary hyperparathyroidism; brown tumor; giant cells; chronic kidney failure.

\section{INTRODUCTION}

Brown tumors are characterized by the local accumulation of fibrous bone tissue and giant cells. They are focal lesions associated with primary or secondary hyperparathyroidism (HPT), which can be invasive in some cases. Although brown tumors are the consequence of HPT (mainly primary and rarely secondary or tertiary), cases associated with chronic renal failure (CRF) have increasingly been reported. In patients with CRF, brown tumors are an extreme form of osteodystrophy. These lesions appear as welldefined areas in the skeleton and are common in long bones, ribs, clavicle and pelvic girdle, although they can occur at any other site, including the maxilla and mandible. Nonetheless, brown tumors involving the last two sites are rare ${ }^{(4,14,18,19)}$.

The name of this metabolic bone lesion is derived from the color of the tissue specimen, which generally ranges from dark red to brown due to the presence of abundant hemorrhage and deposition of hemosiderin inside the tumor. Radiography reveals that brown tumors appear as radiolucent, uni- or multilocular images. The lesions are often solitary, but can also be multiple. Long-term lesions can generate significant expansion of cortical bone $e^{(17)}$.

Brown tumors are caused by the increased osteoclast activity and fibroblast proliferation seen in HPT. Microscopic analysis reveals increased osteoclast activity, higher bone resorption and neoformation, irregular thickening of trabecular bone, peritrabecular fibrosis, multinucleated giant cells, interstitial hemorrhage, and hemosiderin deposition. Regression or complete disappearance of benign lesions is usually observed after parathyroidectomy ${ }^{(13)}$. However, depending on their location and capacity of local destruction, brown tumors can be clinically devastating, occasionally causing pathological fractures. Involvement of the spine is linked with the risk of infarction and neurological deterioration ${ }^{(8,13)}$

In view of the importance of brown tumors, this study reports the case of a patient with secondary HPT and CRF, presenting a lesion in the lateral region of the right maxilla, which had

First submission on 12/07/13; last submission on 05/09/13; accepted for publication on 05/09/13; published on 20/12/13

1. MSc in Health Sciences by Universidade Federal do Rio Grande do Norte (UFRN); dental surgeon at UFRN.

2. MSc in Oral Pathology by UFRN; professor of Dentistry at Universidade Estadual da Paraíba (UEPB).

3. MSc in Oral Pathology by UFRN; PhD student in Oral Pathology at UFRN.

4. PhD in Oral Pathology by UFRN; professor at Centro Universitário do Rio Grande do Norte (UNI-RN); dental surgeon at UFRN.

5. PhD in Oral Pathology by UFRN; professor at Universidade Federal de Campina Grande (UFCG).

6. PhD in Oral Pathology by UFRN; professor at the Dentistry Department and Post-Graduation Program in Oral Pathology at UFRN. 
appeared about 5 months earlier. The clinical, radiographic and histopathological features of this condition as well as its differential diagnosis are discussed herein.

\section{CASE REPORT}

A. S. S., a 36-year-old white woman with secondary HPT, was seen at the Dentistry Service of Hospital Universitário Onofre Lopes (HUOL) for dental assessment prior to kidney transplantation due to CRF. The patient was referred to the Oral Diagnostic Service of the Department of Dentistry, Federal University of Rio Grande do Norte (UFRN), because of a lesion in the lateral region of the right maxilla, which had appeared about 5 months earlier. The patient had systemic arterial hypertension and had been undergoing hemodialysis for 5 years.

Extraoral physical examination revealed facial asymmetry and swelling on the right side (Figure 1). Intraoral examination showed the presence of a sessile, nodular lesion of normal mucosal color and hard/resilient consistency on the right side of the hard palate, corresponding to teeth 13 to 15 (Figures 2 and 3 ). The patient reported pain symptoms at the site of the lesion.

Routine laboratory tests yielded the following results: high levels of creatinine $(7.8 \mathrm{mg} / \mathrm{dl})$, pre $(160 \mathrm{mg} / \mathrm{dl})$ and post-hemodialysis urea ( $46 \mathrm{mg} / \mathrm{dl})$, pyruvic transaminase (52 U/l), alkaline phosphatase (428 $\mathrm{U} / \mathrm{l})$, phosphorus $(7.5 \mathrm{mg} / \mathrm{dl})$, ferritin $(1,006 \mathrm{ng} / \mathrm{ml})$, and parathyroid hormone (PTH) $(1914 \mathrm{pg} / \mathrm{ml})$. In contrast, ionized $(1.08 \mathrm{mmol} / \mathrm{l})$ and serum $(8.3 \mathrm{mmol} / \mathrm{l})$ calcium levels were reduced.

Panoramic radiography showed a round, unilocular and radiolucent area delimited by thin radiopaque cortical bone extending into the lower part of the maxillary sinus. Teeth 13 ,

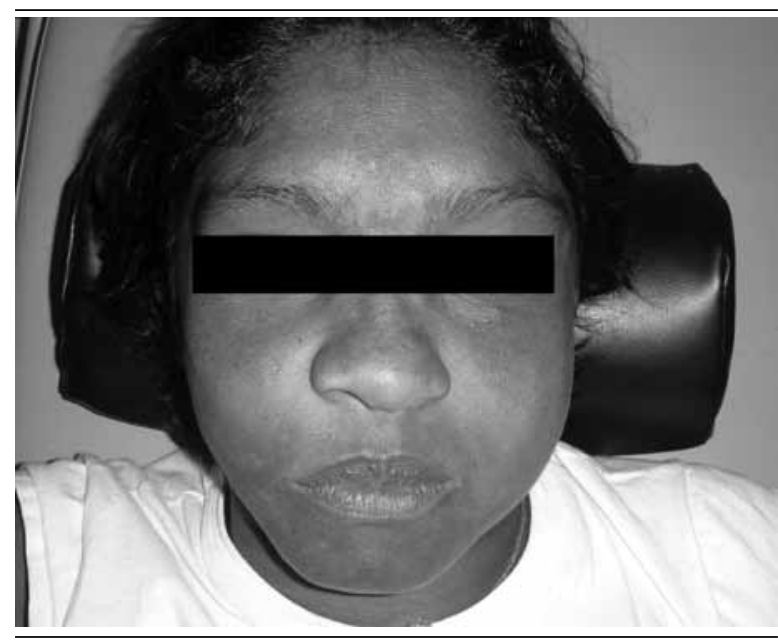

FIGURE 1 - Frontal view of the patient. Note the facial asymmetry on the right side and mild swelling of the maxilla, lifting the nasal wing
14 and 15 were displaced (Figure 4). An expansive/infiltrative mass of heterogeneous density containing very small hypodense areas was observed on computed tomography scans. The mass had irregular contours and partially defined limits. Moreover, it was located in the alveolar process of the right maxilla, extending into the oral cavity and subcutaneous tissue located anterior to the ipsilateral maxillary sinus (Figure 5).

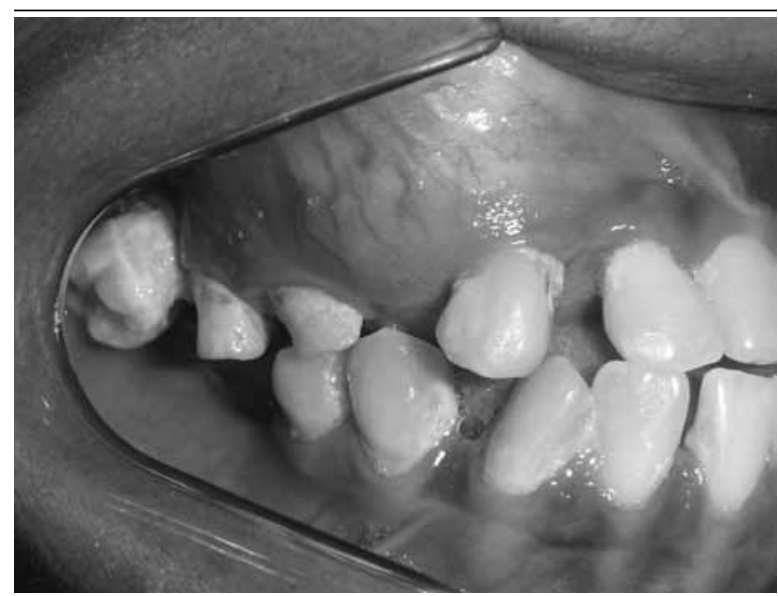

FIGURE 2 -Intraoral aspect, showing increased volume in the vestibular region, on the right side

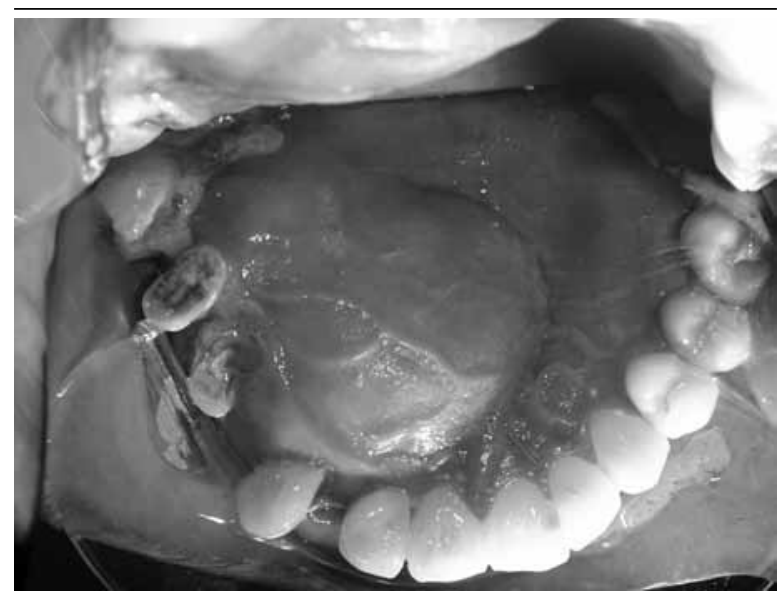

FIGURE 3 -Intraoral aspect of non-ulcerated exophytic lesion with well-defined borders and exhibiting an increase in hard palate bone volume (right view)

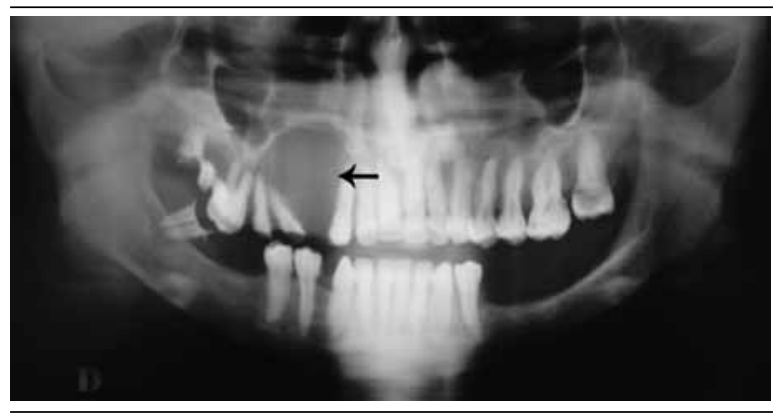

FIGURE 4 -Panoramic $x$-ray exhibiting radiolucent lesion in the root region of tooth elements 13 to 16 


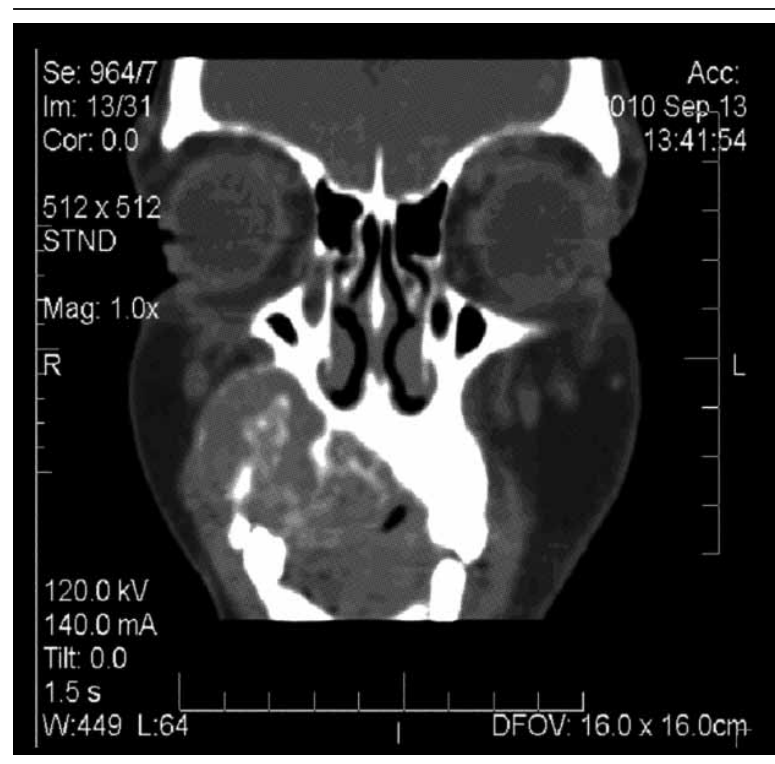

FIGURE 5 -Computerized coronal tomography localized in the anterior right maxillary sinus, showing the lesion and its relationship with the roots of molars

The clinical diagnostic hypotheses were odontogenic cyst, periapical abscess and odontogenic myxoma. An incisional biopsy was performed and histopathological analysis of the specimen revealed the proliferation of round, spindleshaped and oval mesenchymal cells in the lesion as well as the presence of numerous multinucleated giant cells containing hyperchromatic or vesicular nuclei. In addition to these histological features, there was a predominance of loosely organized fibrous connective tissue. Mineralized tissue ranging from osteoid deposition to mature anastomosing bone trabeculae, sometimes paved with osteoblasts and occasional osteoclasts, was also observed (Figures 6 and 7).

Based on careful and detailed anamnesis in conjunction with clinical, radiographic, and histopathological features as well as complementary laboratory tests, the diagnosis of brown tumor associated with secondary HPT was established. Subsequently, the patient underwent parathyroidectomy. Thus, the surgical treatment consisted in removing all four parathyroid glands and their fragments were auto-transplanted into the muscle of the right forearm. This was followed by a significant drop in serum PTH levels and normalization of serum calcium and phosphate, resulting in a small brown tumor regression during the first weeks. Currently, as stipulated by the medical staff of Nephrology and Surgery of Head and Neck-HUOL, the patient is awaiting the surgical removal of the brown tumor, which is commonly performed six months after parathyroidectomy and prior to kidney transplantation.

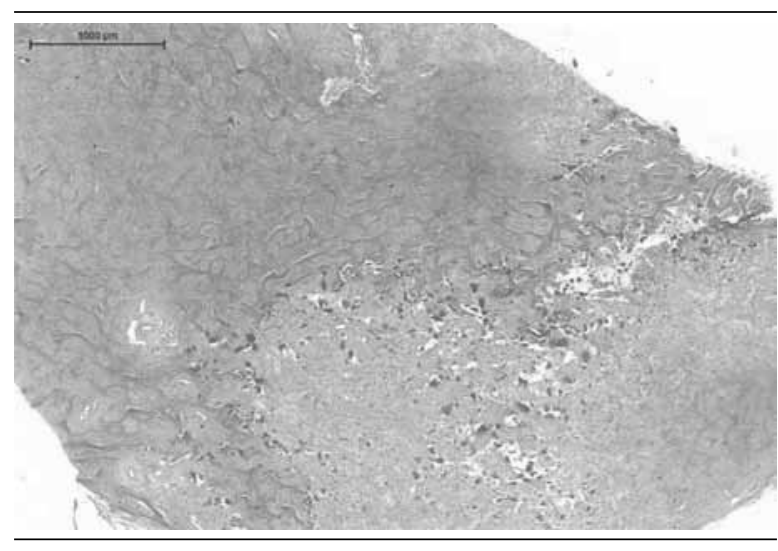

FIGURE $\mathbf{6}$ - Panoramic view of the lesion showing trabecular bone (top) and numerous multinucleated giant cells (bottom) (HE, scale bar: 1000 um)

HE: hematoxylin and eosin.

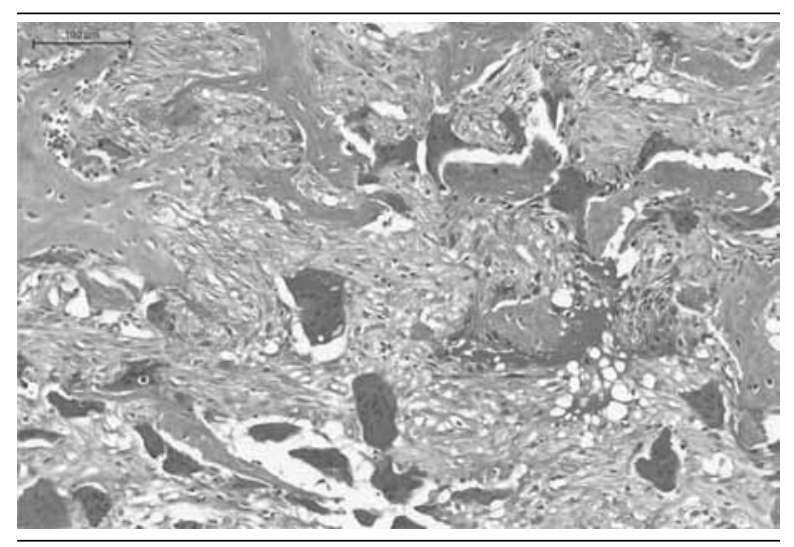

FIGURE 7 - Mineralized trabecular bone and multinucleated giant cells in a connective tissue rich in mesenchymal cells with different forms (HE, scale bar: 100 нm)

HE: hematoxylin and eosin.

\section{DISCUSSION}

HPT falls into three major types: primary, secondary, and tertiary. Primary HPT is the result of an increase in PTH due to autonomous function of the parathyroid gland, which frequently occurs in response to an adenoma (approximately 85\% of cases), hyperplasia or carcinoma. Secondary HPT is caused by calcium or vitamin D deficiency and is commonly observed in patients with CRF. In the present case, ionized $(1.08 \mathrm{mmol} / \mathrm{l})$ and serum $(8.3$ $\mathrm{mmol} / \mathrm{l}$ ) calcium levels were found to be reduced. Tertiary HPT is associated with kidney failure and results from autonomous parathyroid function in patients with long-term secondary $\mathrm{HPT}^{(1)}$. Brown tumors are detected in 3\% to $4 \%$ of patients with primary HPT and in $1.5 \%$ to $1.75 \%$ of cases of secondary HPT ${ }^{(2)}$. Therefore, secondary HPT represents a frequent complication in patients with stage 5 CRF insofar as long-term hemodialysis treatment promotes 
accelerated growth of parathyroid cells ${ }^{(12)}$. In the present case, ultrasonography showed enlargement of the parathyroid gland. The patient had secondary HPT, CRF and had been undergoing hemodialysis for 5 years. Thus, increased PTH secretion represents a basic causal factor of parathyroid gland hyperplasia and secondary HPT associated with bone deformities ${ }^{(10)}$.

Hypocalcemia, hypophosphatemia and the need for calcitriol, vitamin D metabolites and 1,25-hydroxycholecalciferol are common features in patients with CRF, increasing PTH secretion and provoking morphological modifications in the parathyroid glands ${ }^{(6,7,9)}$. As reported earlier, the levels of these substances were altered in the present case.

Bone lesions are among the main manifestations of HPT, ranging from generalized osteopenia, cystic lesions and bone resorption to brown tumors ${ }^{(3)}$. Maxillofacial brown tumors are rare. When they occur in this region, they usually involve the mandible, whereas the maxilla is rarely affected ${ }^{(18,20)}$. In the present case, the brown tumor was located in the maxilla and extended to the palate. Furthermore, brown tumors are three times more frequent in women older than 50 years, but the present patient was only 36 years old, which is a rare finding. Pain, edema, altered masticatory function and esthetic deformity might be present, or the lesion is completely asymptomatic ${ }^{(18)}$.

Morrone et al.$^{(15)}$ reported the case of a 57-year-old man with secondary HPT who developed a brown tumor that concomitantly involved the maxilla and seventh rib. Pinto et al ${ }^{(18)}$ described the case of a 37-year-old woman with painful bilateral and intraoral maxillomandibular swelling. Similarly, the present patient was a 36-year-old woman with a lesion in the hard palate that provoked facial asymmetry and pain symptoms. In a retrospective study of 12 cases of brown tumors associated with secondary HPT, three cases affected the mandible, four the maxillary bone, two the femur, and multiple lesions involving other sites (shoulder, phalanx, femur, and clavicle) were observed in three cases. Calcium levels were elevated in four patients, phosphate levels in 10 cases, and alkaline phosphatase and PTH in all cases ${ }^{(5)}$.

The histopathological characteristics of brown tumors are suggestive, but not sufficient to establish the diagnosis or differentiation from other lesions such as regenerative granuloma, giant cell lesion, giant cell tumor, aneurysmal cyst, cherubism, Paget's disease, odontogenic bone tumor, and non-odontogenic fibrous dysplasia ${ }^{(2,21-23)}$. In the present case, the histopathological features resembled peripheral ossifying fibroma or central giant cell lesion. The diagnosis of brown tumor associated with secondary HPT was established based on careful anamnesis in conjunction with the clinical, radiographic, histopathological features and complementary laboratory tests.

Since brown tumors are frequently asymptomatic, no specific treatment is required ${ }^{(15)}$. However, when affecting the maxilla or mandible, brown tumors can easily obstruct the upper airways and oral cavity, therefore surgical treatment is necessary in these cases. Although they are not regarded as malignant lesions, brown tumors can lead to the death of the patient ${ }^{(11)}$.

Treatment of brown tumors and secondary HPT in patients with CRF includes adequate hemodialysis, a reduction of phosphate intake, and the use of phosphate binders, vitamin D analogs and calcimimetics. In cases in which HPT does not respond to these treatments, parathyroidectomy is recommended ${ }^{(16)}$. Surgery is not indicated in cases in which the growth of the tumor does not compromise adjacent structures or provoke other clinical problems $^{(2)}$. In the present case, there was a slight regression of the lesion noted in the first weeks after the completion of subtotal parathyroidectomy and reduction of serum PTH.

\section{CONCLUSION}

Although uncommon, the occurrence of brown tumors should be considered in patients with secondary HPT and CRF. In most cases, these lesions usually regress or even disappear after removal of the parathyroid gland for the control of HPT, which was the procedure adopted in the present investigation. In addition to being a rare case, it is essential that the dental surgeon be aware of oral manifestations associated with systemic diseases, hence the importance of detailed anamnesis and careful physical examination for the diagnosis and treatment success.

\section{RESUMO}

O tumor marrom é uma lesão óssea que pode acometer todo o esqueleto, inclusive os ossos maxilares. Apresenta-se como uma lesão focal de células gigantes associada ao hiperparatireoidismo (HPT) primário ou secundário; é invasiva em alguns casos e pode associar-se à insuficiência renal crônica (IRC). O presente trabalho descreve um caso de tumor marrom em uma paciente 
de 36 anos com insuficiência renal crônica (IRC), portadora de HPT secundário, que apresentava lesão, com duração de aproximadamente cinco meses, localizada na maxila direita, com o objetivo de auxiliar o diagnóstico diferencial das lesões ósseas que podem afetar pacientes dialíticos.

Unitermos: biperpartireoidismo secundário; tumor marrom; células gigantes; insuficiência renal crônica.

\section{REFERENCES}

1. AHMAD, R. HAMMOND, J. M. Primary, secondary, and tertiary hyperparathyroidism. Otolaryngol Clin N Am, v. 37, p. 701-13, 2004.

2. DANIELE, N. et al. Brown tumor in a patient with secondary hyperparathyroidism resistant to medical therapy: case report on successful treatment after subtotal parathyroidectomy. Int J Endocrinol, v. 12, p. 13, 2009.

3. DE FRANCISCO, A. L. Secondary hyperparathyroidism: review of the disease and its treatment. Clin Ther, v. 26, p. 1976-93, 2004.

4. FATAHZADEH, M. The spectrum of orofacial manifestations in renal osteodystrophy: diagnostic challenges of an uncommon presentation. Quintessence Int, v. 42, p. 78-88, 2011.

5. FATMA, L. B. et al. Brown tumors in patients with chronic renal failure and secondary hyperparathyroidism: report of 12 cases. Saudi J Kidney Dis Transplant, v. 21, n. 4, p. 772-7, 2010.

6. GEOFFREY, A. B. et al. Association of serum phosphorus and calcium $\mathrm{x}$ phosphate. Product with mortality risk in chronic hemodialysis patients: a national study. Am J Kidney Dis, v. 31, n. 4, p. 607-17, 1998.

7. GOODMAN, W.G. et al. Suppressive effect of calcium on parathyroid hormone releaser in a dynamic renal osteodystrophy and secondary hyperparathyroidism. Kidney Int, v. 51, p. 1590-5, 1997.

8. HOSHI, M. et al. A case of multiple skeletal lesions of brown tumors, mimicking carcinoma metastases. Arch Orthop Trauma Surg, v. 128, p. $149-54,2008$.

9. HRUSKA, K. A. Renal osteodystrophy. Baillieres Clin Endocrinol Metab, v. 11, p. 165-94, 1997.

10. JERENSTRUJIC, B. et al. Secondary hyperparathyroidism and brown tumor in dialyzed patients. Renal Failure, v. 23, n. 2, p. 279-86, 2001.

11. KARABEKMEZ, F. E. et al. Huge deforming brown tumour at the maxilla and mandible in a patient with secondary hyperparathyroidism. J Plast Reconstr Aesthetic Surg, v. 61, p. 140-5, 2008.
12. KESTENBAUN, B. et al. Parathyroidectomy rates among United States dialysis patients: 1990-1999. Kidney Int, v. 65, p. 282-8, 2004.

13. MATEO, L. et al. Brown tumor of the cervical spine: a case report and review of the literature. Clin Rheumato, v. 30, p. 419-24, 2011.

14. MONTEIRO, M. L. R. Multiple brown tumors of the orbital walls: case report. Arq Bras Oftalmol, v. 72, p. 116-8, 2009.

15. MORRONE, L. F. et al. Maxillary brown tumor in secondary hyperparathyroidism requiring urgent parathyroidectomy. J Nephrol, v. 14, n. 5, p. 415-9, 2001.

16. NABI, Z. et al. Regression of brown tumor of the maxilla in a patient with secondary hyperparathyroidism after a parathyroidectomy. Hemodialysis International, v. 14, p. 247-9, 2010.

17. NEVILLE, B. W. et al. Patologia oral e maxilofacial. Rio de janeiro: Elsevier, 2009. p. 841-2.

18. PINTO, M. C. et al. Brown tumor in a patient with hyperparathyroidism secondary to chronic renal failure. Braz J Otorbinolaryngol, v. 76, p. $404,2010$.

19. QUEIROZ, S. M. et al. Influence of dialysis duration and parathyroid hormone on the clinical and radiographic oral conditions of pretransplant patients with chronic kidney disease. Braz J Oral Sci, v. 12, n. 2, p. 125-31, 2013.

20. RESÉNDIZ-COLOSIA, J. A. et al. Evolution of maxillofacial brown tumors after parathyroidectomy in primary hyperparathyroidism. Head Neck, v. 30, n.11, p. 1497-504, 2008.

21. SANROMÁN, J. F. et al. Tumor pardo en la sínfisis mandibular como primera manifestación clínica de hiperparatiroidismo: diagnóstico y tratamiento. Med Oral Patol Oral Cir Bucal, v. 10, n. 2, p. 169-72, 2005.

22. SCHOLL, R. J. et al. Cysts and cystic lesions of the mandible: clinical andradiologic histopathologic review. Radiographics, v. 19, n. 5, p. 110724, 1999 .

23. TAKESHITA, T. et al. Brown tumor of the sphenoid sinus in a patient with secondary hyperparathyroidism: CT and MR imaging findings. Case report. Radiat Med, v. 22, n. 4, p. 265-8, 2004.

\section{MAILING ADDRESS}

Hébel Cavalcanti Galvão

Universidade Federal do Rio Grande do Norte; Programa de Pós-Graduação em Ciências da Saúde; Av. Gal. Gustavo Cordeiro de Farias, s/n; Petrópolis; Caixa postal: 244; CEP: 59010-180; Natal-RN, Brazil; Tel.: (84) 3342-9776; e-mail: hebel.galvao@yahoo.com.br. 